\title{
Perceptions of Roles and Responsibilities in Online Learning: A Case Study
}

\author{
Annemieke Craig, Annegret Goold, Jo Coldwell, \\ and Jamie Mustard \\ Deakin University, Victoria, Australia
}

\begin{abstract}
annemieke.craig@deakin.edu.au annegret.goold@deakin.edu.au jo.coldwell@deakin.edu.au jamie.mustard@deakin.edu.au
\end{abstract}

\begin{abstract}
The extensive introduction of online technologies to support teaching and learning is impacting how teachers teach and students learn. It is also affecting both teaching staff's and students' perceptions of what each others' roles are. The research reported here is part of a larger study that explored different aspects of teaching and learning in online environments. This study was undertaken within an Australian university and involved an institution-wide survey of students. The paper reports on students' perceptions of their roles as online learners and the expectations they have of online teachers. The outcomes of the research suggest that different cohorts of students have different expectations. These expectations are informed by their mode of study and also by their perceptions of how staff engage with online teaching. Recommendations include proactive management of student expectations by staff, as well as a commitment by staff to meet those expectations.
\end{abstract}

Keywords: Online learning, E-learning, online teaching, role of online teacher, role of online learner

\section{Introduction}

The widespread introduction of online technologies to support teaching and learning has significantly altered the practice of teaching in many tertiary institutions (Abrioux, 2004). The traditional higher education classroom has increasingly moved from a face-to-face environment to one that is integrated, blended or even replaced by online interaction (Lockyer \& Bennett, 2006). Not only can this new environment provide a rewarding and engaging experience but Singh, O'Donoghue and Worton (2005) suggest that it provides many opportunities for students and in particular can enable them to become self-directed, independent learners and eventually lifelong learners.

Teaching and learning in this online environment, however, involves shifts in both understanding

Material published as part of this publication, either on-line or in print, is copyrighted by the Informing Science Institute. Permission to make digital or paper copy of part or all of these works for personal or classroom use is granted without fee provided that the copies are not made or distributed for profit or commercial advantage AND that copies 1) bear this notice in full and 2) give the full citation on the first page. It is permissible to abstract these works so long as credit is given. To copy in all other cases or to republish or to post on a server or to redistribute to lists requires specific permission and payment of a fee. Contact Publisher@,InformingScience.org to request redistribution permission. and in behavior (Salmon, 2005). This paper explores whether the expectations of the role teachers and students play in the modern, tertiary institution have kept pace with the adoption of online technologies. Although this research is a case study, it is expected that the results and recommendations will be of interest to those involved with the delivery of elearning in the higher education context. 
E-learning, in the context of this research, is the learning processes and interactions between students and teachers that are supported by information and communication technologies (ICT). Recent studies have focused on examining issues related to the implementation and evaluation of e-learning in higher education (Lefoe, Gunn \& Hedberg, 2002; Singh et al., 2005; Wang, 2006). Likewise students' perceptions of e-learning have been explored (see for example Coldwell, Craig, \& Goold, 2006; Keller \& Cernerud, 2002). Other studies have focused on the evaluation of particular courses where online learning environments (OLEs) are used (Goold \& Coldwell, 2005; Smith, Coldwell, Smith, \& Murphy, 2005); or on investigating and evaluating tools and features used in OLEs, as a whole or by particular student cohorts (Herrington \& Oliver, 2002). Where broad-scale research of student evaluations of OLEs has been published, the focus tends to be on the ICT aspects of the OLE.

Publication of research on students' roles in OLEs for learning across a university is limited and usually emphasizes students' attitudes towards, and their perceptions of, the benefits of OLEs (Haywood, Macleod, Haywood, Mogey, \& Alexander, 2004). Insights into the changing role of both teacher and students in OLEs need to be gathered if these environments are to be used in the optimum way (McShane, 2000).

Haywood et al. (2004) report on a longitudinal study of students' preparedness for and perceptions of e-learning in the UK and Europe. They suggest that students enter University with at least a basic level of ICT skills and that they have access to and a willingness to use ICT for study as well as social and recreational activities. Students also have a positive attitude towards the use of ICT to support teaching and learning. However, students are generally unprepared for new learning experiences. They consider the use of ICT as a supplement to traditional teaching only and are concerned about the loss of quality of their learning experience as well as the apparent transfer of burdens and costs to them. Cowan (2006) suggests that the advance of technologies has made syllabi, which require students to know, understand, and apply material, out of date. Instead students need to concentrate on the higher levels of learning in the cognitive domain. Therefore, students need to develop "sophisticated abilities in problem-solving, making judgments, searching, analyzing, thinking critically, and collaborating with others" (Cowan, 2006, p.3). The research by both Cowan and Haywood et al. suggests that generally students require coaching as to what their role is and what the role of the teacher is, to gain the benefits afforded by technology supported education.

A small-scale study reported by Newlands and Coldwell (2004) attempted to address some of the discrepancies between teacher and student expectations. This study did not investigate the skills and attitudes that students bring to online learning but rather their expectations of their online learning experience. The study identified four barriers to learning: responsibility for learning, interaction, use of appropriate learning strategies, and acquisition of required ancillary skills.

While both teachers and students generally have a good understanding of what the roles of teachers and students are in a face-to-face environment, the roles in an online environment can be subtly different. "Online teaching and learning changes the scope and skills we require of academics and teachers. It changes what we actually do with students" (Salmon, 2001, p. 2). For successful teaching and learning to take place, both teachers and students need to be clear on the roles that they are expecting of each other. A mismatch between these expectations can lead to frustration and a less than satisfactory teaching or learning experience. Consequently Chang and Fisher (2003) argue that teachers and students must understand their roles in the online environment if they are to contribute and participate successfully in an OLE. 


\section{The Role of the Teacher}

The role of the teacher in any learning environment is to "ensure that some type of educational process occurs amongst the learners involved" (Chang \& Fisher 2003, p. 5). In the traditional classroom the teacher's role can be seen as that of an instructor imparting knowledge to students as well as advice on "how to do it" (Cowan, 2006, p.5). Conti (1985) refers to the teachercentered style as one in which the responsibility for directing the learning environment is the instructor. Jarvis (1995) suggests that this style of teaching relies on strategies aimed at transmitting knowledge to the learners. However, the role of the teacher in tertiary institutions "needs to change to match the development and potential of new online environments" (Salmon, 2002, p. 3 ). Teaching successfully in an online environment does not come from teachers doing what they have always done (Salmon, 2002). In an OLE the teacher's role becomes that of an educational facilitator, providing guidance and fostering "a sense of community among learners" (Chang \& Fisher, 2003, p. 5).

It has been suggested that the online teacher needs to adopt the roles of facilitator and coach (Lai, 1999) combined with moderator and tutor (Cowan, 2006) as well as subject matter expert and technician (Anderson, 2004). Aggarwal and Bento (2000) suggest that the teacher in the online environment also needs to assume the role of mentor; whereas Chan (2003) proposes that the role of adjudicator be included. Goodyear, Salmon, Spector, Steeples, and Tickner (2001) developed a model which encompasses eight roles for the online teacher, those of content facilitator, technologist, designer, manager/administrator, process facilitator, adviser/counselor, assessor and researcher (see Table 1).

\begin{tabular}{|l|l|}
\hline \multicolumn{2}{|c|}{ Table 1: Roles and indicators of key competences of the online teacher } \\
(Source: Goodyear et al., 2001, pp. 69-70)
\end{tabular}

Salmon (2001) describes the person who is responsible for responding to and building on the contributions of online discussions as an e-moderator. While in some instances the e-moderator or online tutor or teaching assistant may be a separate person, in the context of many tertiary institutions e-moderation is considered part of the teacher's role. In the context of this research the emoderation is considered to be only one part of the role of the teaching staff involved. King (1993) defined the role of the e-moderator as "the guide on the side" (versus "sage on the stage") which Collison, Elbaum, Haavind, and Tinker (2000) suggest is the most appropriate role for leading a virtual learning community. They also suggest that the tasks of an online instructor or tutor should include: being aware of all postings within discussion forums; encouraging participation and keeping track of the involvement of individual students; keeping the discussion focused; and encouraging higher order thinking. 
Mazzolini and Maddison (2006), among others, support the role of the instructor as the person who allows students to adopt a more central role in their own learning. A number of authors have suggested that the new paradigm has therefore seen a shift from teacher-centered and institutioncentered learning, to learning that is student-centered (see for example Barrett, 2006; Butler, 2000; Chang \& Fisher, 2003).

Stacey (2000) suggests that the online teacher will therefore need to provide the discipline knowledge and the organization, design, management and sequencing of learning, as well as the social presence through online interaction.

\section{The Role of the Student}

Students need to take an active approach to learning if they are to be successful online learners (Palloff \& Pratt, 1998). Consequently students need to be involved in discussions, be prepared to speak out, develop solutions, and work within minimal guidelines. Further, generating deeper levels of understanding requires students to work collaboratively (Chang \& Fisher, 2003).

Zariski and Styles (2000) suggest that students need to become self-directed learners, which require them to be highly self-regulated, be responsible for organizing their learning, and be reflective. Students who are self-directed learners will understand content plus have a positive attitude towards themselves as learners. This will enable them to reflect on their learning and will provide the motivation to continue learning throughout life (Clayton, 2003). Armarego and Roy (2000) argue that by having students complete reflective journals, or some other measure of self assessment, they have opportunities for reflection and introspection so that they can make sense of the experiences they have gained. An "e-learner must be able to identify and prioritize his or her personal skill gaps" and "manage the learning experience, including setting clear goals, establishing specific plans, and securing needed resources" (Birch, 2002).

Quek and Wong (2003, p.289) warn that being successful in the online environment requires that students understand the purpose and function of online learning. This will need to be made explicit and involves giving both teachers and students time to be comfortable in using the tools provided in the online environment.

\section{The Study Environment}

The research presented here is part of a larger study that was supported by a Strategic Teaching and Learning Grant at Deakin University in 2005. The overall study was investigating different aspects of cultural diversity, as perceived by teachers and students, in the online learning environment (OLE). The study used a variety of data-gathering techniques including a literature review, focus groups with teaching staff, and a university-wide online survey of students. The perceptions of students of their role and the role of a university teacher, particularly in the context of online learning environments, are discussed in this paper.

Deakin University is a multi-campus institution catering for local and international students studying in a wide variety of disciplines within arts, teacher education, science and technology, and health sciences including nursing, at both undergraduate and postgraduate levels. Students study on campus or off campus. The University has a long tradition of using information and communication technologies (ICT) to support distance education students, particularly to facilitate communication between teaching staff and students. More recently the strategic direction of the University has been to incorporate online technologies into the learning experience of all students, encouraging the use of "... a comprehensive learning environment through integrated networked technologies to enrich learning experiences for off-campus and multi-modal students as well as for on-campus students" (Deakin University, 2004a). Distance education students can expect a learning experience that incorporates traditional paper-based resources, but increasingly 
resources are provided electronically as well. There is an expectation that they will interact with teachers and students in online classrooms, taking part in discussions and virtual tutorials, and undertake group work facilitated by the technology.

Distance education students are not the only ones to experience the impact of technology on their learning experience. Deakin University endeavors to provide as similar a learning experience as possible to all students. This has traditionally entailed attempting to match an off-campus learning experience to an on-campus one. The trend now is for a balanced approach with both oncampus and off-campus students exposed to online learning. On-campus learning therefore has evolved into a blended mode with traditional face-to-face teaching methods being supplemented, enhanced, and in some cases replaced, by online teaching methods. This is supported by the current OLE, which is implemented using WebCT Vista (now BlackBoard Vista).

The University is committed to preparing students for lifelong learning and has mandated that every undergraduate must experience at least one wholly online course during the degree program (Deakin University, 2003). A wholly online course is defined as one where all teaching and administrative support is provided online. Essentially this means that there is no face-to-face teaching in the course at all. A key characteristic of a wholly online course is that it is designed to help students to develop their skills in communicating and collaborating in an online environment while studying the course curriculum. There are two further levels of online presence defined by the University. An extended online presence is one where at least one major teaching activity, such as lectures, tutorials, assessment or workshops, occurs wholly online or is significantly supplemented by online technologies. A basic online presence entails administrative support, providing students with a first and main point of administrative contact for the course online. This is the lowest level of online capability and a minimum requirement for all courses.

Evidence provided by surveys previously undertaken within Deakin University (Deakin, 2005) suggested that students were not in wholehearted agreement with the University's approach to online learning. Although they generally agreed that online learning environments enhanced the teaching and learning experience, wholly online courses were not necessarily considered a good approach, with many students suggesting that they were simply a cost-cutting measure. This suggested that there was a lack of understanding by students as to why they are expected to complete

online courses. Further, it suggested that there was an inconsistency with the way in which online learning and teaching is viewed by students and teachers and, also, what role each is expecting the other to play.

\section{Methodology}

The research design included gathering data from both staff and students at the University. The first part of the project was a series of focus groups with purposefully selected staff experienced with online course design, development, implementation, or operation (teaching). These were held during mid-2005. Focus groups are useful to explore whether there is a common view as suggested by Barnett (2006, p. 2), "The goal in organizing focus groups is to investigate consensus experience, or attitudes/beliefs related to a clearly defined topic." The teaching staff represented a broad range of areas and were from all faculties and campuses across the University. While focus groups were not asked specifically about roles of staff and students in the online environment, they did provide an insight into what their role in online teaching was, as well as what they expect the students' role to be.

The findings of these focus groups were then benchmarked with external teaching staff through a workshop at the Asia-Pacific WebCT User Conference in September 2005, involving 20 Australian and international participants. 
An online student questionnaire was deemed the most appropriate survey instrument for the final part of the study. This questionnaire aimed to gain a representative student sample as well as being the least demanding method, in terms of time and resources, to implement and administer. Thomas (2004) provides the rationale for the choice of online survey. The questionnaire was posted on the University's intranet in September 2005 and was made available for two weeks to all students enrolled at the University. The students received an invitation to participate via a message posted on the Student Portal as well as an announcement in the OLE. The incentive to participate was the opportunity to win an MP3 player.

The survey consisted of 60 questions. These questions were either suggested by the literature or developed by the researchers in brainstorming sessions. The questions sought responses to:

- demographics (age, gender, country of birth, language, cultural background); studies at Deakin (mode of study and enrolment, enrolled faculty, major area of study, experience with online courses);

- perceptions of the OLE;

- perceptions of group work;

- perceptions of the role of teaching staff;

- perceptions of their role as a student; and

- expectations of learning generally, and of learning online.

Most of these questions required a 5-point Likert type response from 'Strongly Agree' to 'Strongly Disagree' or a 'yes/no' response. There were also a number of open-ended questions that required a free text response. The software tool NVivo was used to analyse the free text comments.

The responses to the last three questions above - the perceptions of the role of teaching staff; the perceptions of the role of students; and the expectations of learning - are the focus of this paper.

\section{Results}

\section{Student Survey}

In 2005 Deakin University had an enrolment of over 32,300 students (Deakin University, 2006) spread over five campuses: two city, two regional, and one rural campus. Student enrolments are categorized in a number of ways, including attendance at campus and by mode of study. The majority $(60 \%)$ of students were enrolled in on-campus mode while $40 \%$ were enrolled in offcampus or distance mode. The latter included off-shore students who study overseas at partner institutions. All off-campus students are assigned a home campus, usually a regional or rural campus, for administrative reasons.

Nearly $60 \%$ were full-time students and $57 \%$ were female. A standard three-year undergraduate degree is made up of 24 courses completed over six semesters. Full-time students therefore normally undertake four courses per semester. In a normal semester a full-time student would be expected to access up to four of 1500 undergraduate or 700 postgraduate courses via the online learning environment.

The total number of completed surveys was 2711 . Ten of these were unusable and were not included in the data analysis. The size and range of the student responses are considered to be representative of the student population as a whole. Table 2 lists the demographics of the students who responded to the survey. 


\begin{tabular}{|l|l|c|c|}
\hline \multicolumn{4}{|c|}{ Table 2: Student Survey Demographics } \\
\hline \multirow{4}{*}{ Age } & & Total Number & Percentage \\
\hline \multirow{2}{*}{ Gender } & $<20$ & 389 & 14.4 \\
\cline { 2 - 4 } & $20-25$ & 1367 & 50.6 \\
\cline { 2 - 4 } & $>25$ & 945 & 35.0 \\
\hline \multirow{3}{*}{ Mode of Study } & Male & 1055 & 39.0 \\
\cline { 2 - 4 } & Female & 1646 & 61.0 \\
\hline \multirow{3}{*}{ Mode of Enrolment } & Full-time & 1929 & 71.4 \\
\cline { 2 - 4 } & Part-time & 772 & 28.6 \\
\hline \multirow{2}{*}{ Country of Birth } & On-campus & 1868 & 69.2 \\
\cline { 2 - 4 } & Off-campus & 833 & 30.8 \\
\hline \multirow{3}{*}{ Previously Completed an Online Course? } & Australia & 1838 & 68.0 \\
\cline { 2 - 4 } & Asia region & 441 & 16.3 \\
\cline { 2 - 4 } & Other & 442 & 15.7 \\
\hline & Yes & 1487 & 55.0 \\
\cline { 2 - 4 } & No & 1214 & 45.0 \\
\hline
\end{tabular}

\section{Students' Views of the Teacher's Role}

The question that explored students' perceptions of the role of the teacher was: "I believe that the teacher's role at University is to ... (please tick all that apply)". For this question, 14 options were identified by the researchers with an additional 'other' option to allow students to suggest other roles. The researcher-selected options for this question were informed from the literature, the outcomes from staff focus groups and from the researchers' online teaching experiences. The results are shown in Table 3 and are ordered by frequency of mention.

\begin{tabular}{|c|c|c|c|}
\hline \multicolumn{4}{|c|}{ Table 3: Roles and responsibilities of teachers } \\
\hline \multicolumn{2}{|r|}{ Student reflection of teacher role } & \multirow{2}{*}{$\begin{array}{c}n \\
2487\end{array}$} & \multirow{2}{*}{$\begin{array}{c}\mathbf{\%} \\
92.1\end{array}$} \\
\hline $\mathrm{T} 1$ & Provide useful feedback on my work & & \\
\hline $\mathrm{T} 2$ & Provide guidance in discussions & 2260 & 83.7 \\
\hline $\mathrm{T} 3$ & Challenge me to think about issues & 2024 & 74.9 \\
\hline $\mathrm{T} 4$ & Provide stimulating experiences & 2001 & 74.1 \\
\hline T5 & Provide challenging experiences & 1970 & 72.9 \\
\hline T6 & Help me to learn & 1870 & 69.2 \\
\hline $\mathrm{T} 7$ & Be available when I need them & 1643 & 60.8 \\
\hline $\mathrm{T} 8$ & Use language that I can understand & 1330 & 49.2 \\
\hline T9 & Tell me exactly what I need to know & 1146 & 42.4 \\
\hline $\mathrm{T} 10$ & Tell me how to do things & 912 & 33.8 \\
\hline T11 & Conduct research & 869 & 32.2 \\
\hline T12 & Speak my language & 505 & 18.7 \\
\hline T13 & Tell me when to do things & 481 & 17.8 \\
\hline T14 & Know all the answers & 433 & 16.0 \\
\hline $\mathrm{T} 15$ & Other & 197 & 7.3 \\
\hline
\end{tabular}


Figure 1 shows the results in a graphical manner. Clearly, providing feedback and guidance are considered to be the primary roles of teachers. Challenging students to think, providing stimulating and challenging experiences, and helping students to learn, are not far behind. Over $60 \%$ of respondents thought that teachers should be available as needed, although only $16 \%$ thought that teachers should know all the answers. Surprisingly only $32 \%$ of respondents considered conducting research to be a role of teachers; yet at our University the normal workload of teaching staff is $40 \%$ teaching, $40 \%$ research and $20 \%$ administration. Research is often conducted during the non-teaching semester however.

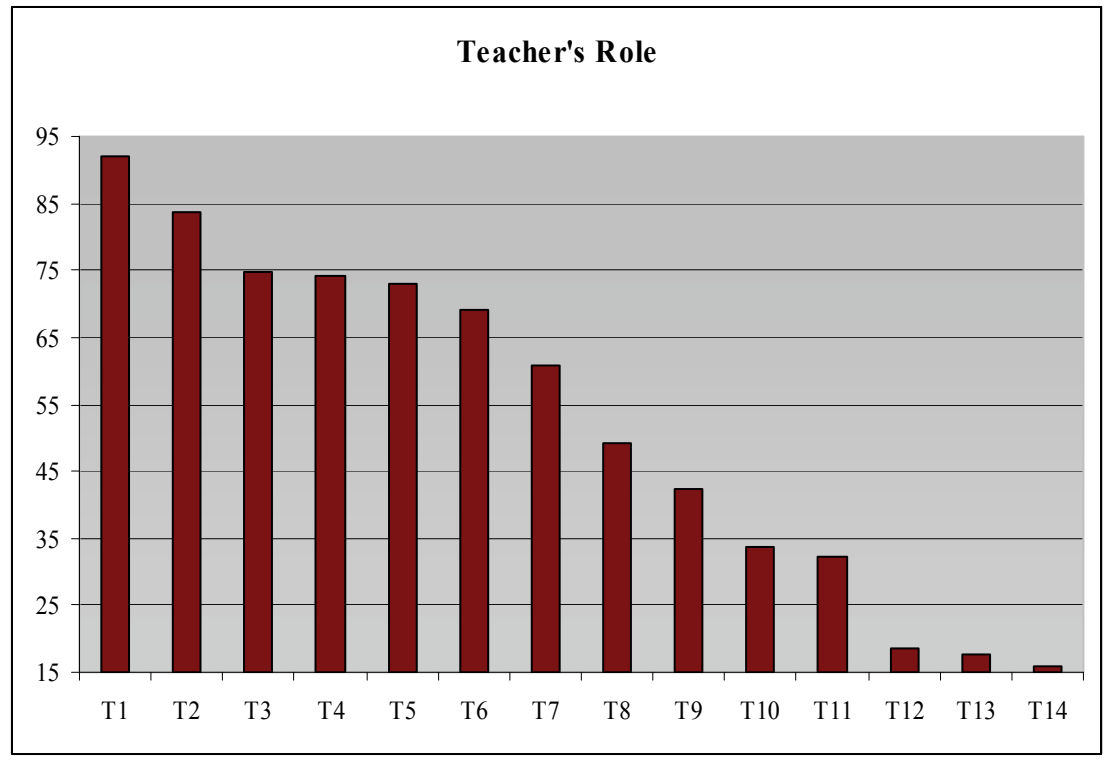

Figure 1: The teacher's role is ...

Of the 197 'other' responses most were variations on those already identified (see list in Table 3). The roles of teachers not previously identified but listed by students were:

- provide resources to support student study $(n=23)$.

- prepare students for their future $(n=11)$

- undertake class management functions $(n=9)$.

Determining whether students' perceptions of the role of teachers varied across the different campuses was also of interest. As mentioned earlier, students study at either a city, regional, or country campus or they study externally either in distance mode or off-shore. For each of the fourteen questions, a Chi-square test of independence was conducted to see whether any variation existed amongst the different campuses. In all cases except for options T2, T7 and T11 statistically significant differences were found (see Table 6 in the appendix). The tables showing the statistics (Tables $6-11$ inclusive) have been included in the appendix to aid readability within the body of the paper.

Post hoc analysis was applied to identify where the variation actually occurred, which showed that off-campus or distance students deviated away from the other groups across all questions (Table 7). This is not surprising for many of the questions, such as those relating to language (options T8 and T12), since distance students tend to have little or no verbal communication with the teaching teachers. Also, for questions relating to the pacing and nature of learning (T6, T7, T9, T10, T13), the variation of distance students may be explained by the fact that their study is often 
self-paced within academic constraints, and many of the students are of mature age and would take a greater responsibility for their learning.

In contrast to distance students, students from the city campuses appeared to have the greatest reliance or expectations about the roles of teachers, particularly with issues relating to the management and guidance of their learning. Regional and country students tend to fall in-between the city and off-campus cohorts.

\section{Students' Views of the Student Role}

The main question that specifically explored students' perceptions of their role was: "I believe that my role as a student at University is to ... (please tick all that apply)". For this question, 12 options were identified by the researchers. Again, an additional 'other' option was included to allow students to suggest other roles not previously identified by the researchers. The results are shown in Table 4 and are ordered by frequency of mention.

\begin{tabular}{|l|l|c|c|}
\hline \multicolumn{4}{|c|}{ Table 4: Roles and responsibilities of students } \\
\hline \multicolumn{2}{|c|}{ Student reflection of student role } & $n$ & $\%$ \\
\hline S1 & Be self-motivated & 2411 & 89.3 \\
\hline S2 & Submit work on time & 2399 & 88.8 \\
\hline S3 & Submit work which is my own & 2366 & 87.6 \\
\hline S4 & Be aware of the requirements in my subjects & 2296 & 85.0 \\
\hline S5 & Allocate sufficient time to complete my studies & 2275 & 84.2 \\
\hline S6 & Ask for help when I'm not sure & 2221 & 82.2 \\
\hline S7 & Explore ideas rather than just remember facts & 2187 & 81.0 \\
\hline S8 & Be prepared for classes & 2098 & 77.7 \\
\hline S9 & Find out what I need to know & 2026 & 75.0 \\
\hline S10 & Express my opinion & 1793 & 66.4 \\
\hline S11 & Be aware of the relevant university legislation & 1703 & 63.1 \\
\hline S12 & Memorize all the answers & 306 & 11.3 \\
\hline S13 & Other & 109 & 4.0 \\
\hline
\end{tabular}

Figure 2 shows the results in a graphical manner. Clearly, students see that it is their responsibility to understand requirements and University legislation; submit work which is their own in a timely manner; prepare for classes, and ask for help when needed; and, above all, motivate themselves. Over $80 \%$ agreed that it was important to explore ideas and conversely only $11 \%$ agreed that memorizing answers was part of their role. 


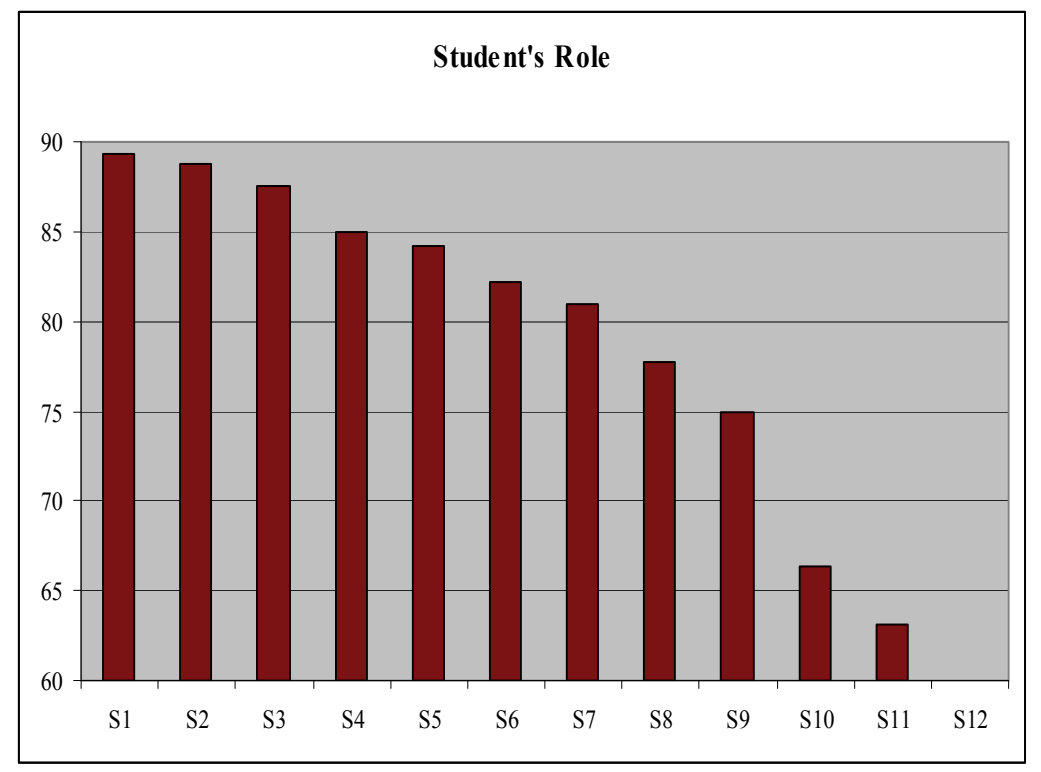

Figure 2: The student's role is ...

Of the 109 'other' roles mentioned, the two suggestions volunteered most frequently related to students taking responsibility for their own learning $(n=51)$ and being proactive $(n=27)$. "Enjoying what I learn" $(n=9)$ and developing generic skills $(n=8)$ were the next two most frequently mentioned roles/responsibilities.

For the 12 questions, a Chi-square test of independence was conducted to see whether any variation existed amongst the different campuses. This time, little or no significant variations for most of the questions relating to the student's role was found. The exceptions were options S1 (self motivation), S3 (submit own work) and S8 (prepared for class). The results are in Table 8 of the appendix.

$\mathrm{S} 1$ (self motivation) is the most interesting of the results with significantly fewer city-based and overseas students acknowledging that self-motivation is important. The results for S3 (submit own work) and S8 (prepared for class) were more or less as expected. Relatively fewer overseas students listed submitting their own work as important. As off-campus students rarely attend classes it is not surprising that fewer put down the need for being prepared for class (Table 9 in the appendix).

There were a number of questions on the survey that related to students' expectations of the University experience, learning, and online learning. Table 5 shows the responses to those questions. Each question used a five-point Likert scale from strongly agree (SA) to strongly disagree (SD).

Overall there is a very high proportion of respondents who generally agreed across all questions except (not surprisingly) for "I accept what we are taught without questioning much" with only $30 \%$ responding positively (although even $30 \%$ could be considered high in this context). 
Table 5: Students' expectations of university experience

\begin{tabular}{|c|c|c|c|c|c|c|}
\hline & Students reflecting student expectations & SA & $\mathbf{A}$ & $\mathbf{N}$ & $\mathbf{D}$ & SD \\
\hline \multirow[t]{2}{*}{ E1 } & \multirow[t]{2}{*}{ I want to develop skills and knowledge for my career. } & 1877 & 670 & 144 & 6 & 4 \\
\hline & & $69.5 \%$ & $24.8 \%$ & $5.3 \%$ & $0.2 \%$ & $0.1 \%$ \\
\hline \multirow[t]{2}{*}{$\mathrm{E} 2$} & \multirow{2}{*}{$\begin{array}{l}\text { I believe what I learn will help me to develop as a } \\
\text { person and broaden my horizons. }\end{array}$} & 982 & 1323 & 338 & 50 & 8 \\
\hline & & $36.4 \%$ & $49.0 \%$ & $12.5 \%$ & $1.9 \%$ & $0.3 \%$ \\
\hline \multirow[t]{2}{*}{ E3 } & \multirow{2}{*}{$\begin{array}{l}\text { My focus is on doing the very best that I can in my } \\
\text { studies. }\end{array}$} & 1220 & 1092 & 335 & 53 & 1 \\
\hline & & $45.2 \%$ & $40.4 \%$ & $12.4 \%$ & $2.0 \%$ & $0.0 \%$ \\
\hline \multirow[t]{2}{*}{ E4 } & \multirow{2}{*}{$\begin{array}{l}\text { My focus is on making the most of all the opportuni- } \\
\text { ties that are available to me. }\end{array}$} & 666 & 1178 & 717 & 126 & 14 \\
\hline & & $24.7 \%$ & $43.6 \%$ & $26.5 \%$ & $4.7 \%$ & $0.5 \%$ \\
\hline \multirow[t]{2}{*}{ E5 } & \multirow{2}{*}{$\begin{array}{l}\text { My focus is on completing my course as quickly as } \\
\text { possible. }\end{array}$} & 835 & 833 & 650 & 331 & 52 \\
\hline & & $30.9 \%$ & $30.8 \%$ & $24.1 \%$ & $12.3 \%$ & $1.9 \%$ \\
\hline \multirow[t]{2}{*}{ E6 } & \multirow{2}{*}{$\begin{array}{l}\text { It is important that I understand the relevance of what } \\
\text { we are expected to learn }\end{array}$} & 1196 & 1189 & 294 & 21 & 1 \\
\hline & & $44.3 \%$ & $44.0 \%$ & $10.9 \%$ & $0.8 \%$ & $0.0 \%$ \\
\hline \multirow[t]{2}{*}{ E7 } & \multirow{2}{*}{$\begin{array}{l}\text { I accept what we are taught without questioning it } \\
\text { much }\end{array}$} & 107 & 706 & 800 & 898 & 190 \\
\hline & & $4.0 \%$ & $26.1 \%$ & $29.6 \%$ & $33.2 \%$ & $7.0 \%$ \\
\hline \multirow[t]{2}{*}{ E8 } & \multirow{2}{*}{$\begin{array}{l}\text { I am prepared to ask the teacher for help whenever I } \\
\text { am unsure of anything }\end{array}$} & 679 & 1311 & 522 & 168 & 21 \\
\hline & & $25.1 \%$ & $48.5 \%$ & $19.3 \%$ & $6.2 \%$ & $0.8 \%$ \\
\hline \multirow[t]{2}{*}{ E9 } & \multirow{2}{*}{$\begin{array}{l}\text { I am prepared to ask other students for help whenever } \\
\text { I am unsure of anything }\end{array}$} & 585 & 1268 & 599 & 225 & 24 \\
\hline & & $21.7 \%$ & $46.9 \%$ & $22.2 \%$ & $8.3 \%$ & $0.9 \%$ \\
\hline \multirow[t]{2}{*}{ E10 } & \multirow[t]{2}{*}{ My participation in scheduled classes is important } & 559 & 1030 & 861 & 188 & 63 \\
\hline & & $20.7 \%$ & $38.1 \%$ & $31.9 \%$ & $7.0 \%$ & $2.3 \%$ \\
\hline
\end{tabular}

When divided up on a campus basis, five of the above ten questions relating to the student experience showed statistically significant differences across the campuses. Chi-square statistics for these questions are provided in Table 10 of the appendix. It should be noted that to meet the assumptions of the Chi-square distribution, the 'strongly agree' and 'agree' responses were aggregated into 'generally agree.' Likewise the 'strongly disagree' and 'disagree' responses were aggregated into 'generally disagree'.

Following on from the Chi-square tests, the post hoc analysis (Table 11 in the appendix) once again revealed that off-campus students tended to stand apart from the other groups. They were less likely to ask other students for help (E9) and were also less concerned with making the most of available opportunities (E4) or completing their studies as quickly as possible (E5).

\section{Discussion}

Universities are concerned with the recruitment, retention, and progression of their students. Providing a positive transition for incoming students is an important area with most universities implementing various first-year initiatives and orientation programmes. An aim of such programmes is frequently to provide students with realistic expectations of the university learning experience. A component of this is for students to understand their role as students, as well as what they can realistically expect from teachers. While many universities provide student charters to articulate these expectations, such as the Deakin University Student Charter (2004b), it is questionable how many students fully comprehend or even take notice of them. 
To eliminate or minimize the discrepancies between these expectations, it is necessary to have an understanding of what today's students see as their role and what expectations they have of university teachers. Equally it is necessary to know the expectations that teachers have of students, and of their own role in the teaching and learning partnership.

From anecdotal evidence within the University, teachers at the city campus hold the view that their students have quite different expectations from students at regional campuses with respect to online learning in particular. These views are supported to a lesser extent by teachers at the regional and rural campuses. The results presented here support this view and various factors could be at play here.

Firstly, there is a higher proportion of international students at the city campuses than at either the regional or rural ones. Indications are that international students have a higher dependency on teacher input into their learning than local students. This may be a cultural factor.

Secondly, teachers at the city campuses have little or no experience dealing with off-campus students. This research suggests that teaching in distance education mode is a good training ground for online teaching. Wholly online teaching involves no face-to-face contact, as with distance education, but includes a high level of online communication. City campus teachers are familiar (and possibly comfortable) with a teacher-centric mode of delivery and are maintaining this mode despite the advent of the more student-centered technologies in their teaching portfolio.

This has significant ramifications for teaching online. Regional teachers are experienced at dealing with the special requirements of distance education whereas city campus teachers are not. Online requires many of the skills that teaching at a distance requires as teachers do not see students face-to-face.

As for the expectations of off-campus students, the differences here are not unexpected. These students have not had the opportunity to communicate extensively with other students or teachers other than via email until recently with the advent of the institutional OLE. Anecdotal evidence garnered through our teaching practice suggests that a small proportion of off-campus students can be quite vocal in the online environments (it is as if they have been let off the leash) but the majority still act as traditional distance learning students. This could be due to a range of factors including the amount of time off-campus students allocate to their studies, as well as to the priority they give study amongst the other priorities of their day-to-day lives.

Further, off-campus students do not have the opportunity of availing themselves of on-campus facilities and so are less likely to give "make the most of opportunities" a high rating.

It is surprising that off-campus students are not concerned with completing as quickly as possible. However, this question may have been misinterpreted as meaning completion in minimum time, which for most full time students is three years. For most off-campus students who study part time, this is totally unachievable.

\section{Conclusions}

The assumption by off-campus students that participation is not a high priority has significant ramifications for online teaching. Distance education students are expected to operate within the OLE to the same extent as on-campus students. If they are not prepared to do so this will have a negative impact on their learning outcomes. The University will need to ensure that such students are not disenfranchised through increasing demands on their time and resources as a result of the need to participate in collaborative learning. Where online participation is required, students should be advised well in advance and educated as to why they are expected to learn in the online environment. 
The teacher-maintained bias against online learning at the city campuses also needs to be addressed. This is having a negative impact on students' online learning experience. A major thrust of the University to ensure students graduate with lifelong learning skills is likely to be jeopardized if students are not encouraged to participate fully in the online learning experience. A recommendation to the University will be the need for staff development to ensure that all University staff have the key skills in online teaching so that all students get more of a uniform educational experience no matter on which campus they are based.

Finally, the perceptions that students have of what their role is, what the role of teaching staff is, and what they can expect from their university experience needs to be carefully cultivated to ensure that any discrepancies are minimized. Further, teaching staff need to be aware of what students expect of them as online teachers and should endeavor to manage and meet those expectations proactively.

Although wholly online learning is a pedagogy that prepares students for lifelong learning as well as operating efficiently and effectively in technology supported work environments, future work needs to be undertaken to determine what impact online learning has on learning outcomes, specifically on the grades achieved. Students need to be convinced of the benefits of wholly online learning before they are accepting of it. Further work also needs to be undertaken on improving the support for preparing teachers to teach online; and on investigating the impact of such programmes on the satisfaction levels of both teachers and students.

\section{References}

Abrioux, D. (2004). Foreword. In T. Anderson \& F. Elloumi (Eds.), Theory and practice of online learning. Athabasca University.

Aggarwal, A. K., \& Bento, R. (2000). Web-based education. In A. Aggarwal (Ed.), Web-based learning and teaching technologies: Opportunities and challenges (pp. 2-16). Hershey, PA: Idea Group.

Anderson, T. (2004). Teaching in an online context. In. T. Anderson \& F. Elloumi (Eds.), Theory and practice of online learning (pp. 271 - 294). Athabasca University.

Armarego, J., \& Roy, G. (2000). Management of a student centred online environment. Retrieved February 9, 2006, from http://cea.curtin.edu.au/tlf/tlf2000/armarego.html

Barnett, J. (2006). Focus groups tips for beginners. TCALL Occasional Research Paper No.1. Retrieved August 2, 2006, from http://www-tcall.tamu.edu/orp/orp1.htm

Barrett, K. R. (2006). Gender and differences in online teaching styles. In E. Trauth (Ed.), Encyclopedia of gender and information technology, Vol. 1 (A-G), (pp. 372-377). London: Idea Group.

Birch, P. D. (2002). E-learner competencies. Learning Circuit. Retrieved December 5, 2006, from http://www.learningcircuits.org/2002/jul2002/birch.html

Butler, J. (2000). Is the Internet helping to create learning environments? Campus-Wide Information Systems, $17(2), 44-48$.

Chan, E. (2003). Exploring the roles of teachers in computer mediated communication activities. World Conference on Educational Multimedia, Hypermedia and Telecommunications 2003, Chesapeake, VA, AACE.

Chang, V., \& Fisher, D. (2003). The validation and application of a new learning environment instrument for online learning in higher education. In M. Khine \& D. Fisher (Eds.), Technology-rich learning environments: A future perspective (pp. 1-20). Singapore: World Scientific.

Clayton, J. (2003). Assessing and researching the online learning environment. In M. Khine \& D. Fisher (Eds.), Technology-rich learning environments: A future perspective (pp. 157-186). Singapore: World Scientific.. 
Coldwell, J., Craig, A., \& Goold, A. (2006). Student perspectives of online learning. Edinburgh: ALT-C.

Collison, G., Elbaum, B., Haavind, S., \& Tinker, R. (2000). Facilitating online learning: Effective strategies for moderators. Madison, WI, USA: Atwood Publishing.

Conti, G. J. (1985). Assessing teaching styles in adult education: how and why. Lifelong Learning, 8(8), 7$11,28$.

Cowan, J. (2006). Introduction. In J. O'Donoghue, Technology supported learning and teaching - A staff perspective (pp. 1-13). London: Idea Group.

Deakin University (2003). Online technologies in courses and units - Operational policy. Retrieved January 27,2006 , from http://theguide.deakin.edu.au/TheDeakinGuide.nsf/Web+Visitors?OpenFrameSet\&Frame=WebConten $\underline{\mathrm{t} \& \mathrm{Src}}=\mathrm{WI} 2.1$ ? OpenPage $\&$ Choice $=0 \&$ Access $=$ Visitor

Deakin University (2004a). Deakin online management plan 2003-2006. Retrieved January 27, 2006, from http://theguide.deakin.edu.au/TheDeakinGuide.nsf/2027c14656ac68f37ca256bad0011d49e/db963375a a298c9fca256ea60083a6c0?OpenDocument

Deakin University (2004b). Student charter. Retrieved January 27, 2006, from http://theguide.deakin.edu.au

Deakin University (2005). DSO (WebCTVista) evaluation report, semester 1 2005. [Internal report.]

Deakin University (2006). 2006 pocket statistics. Planning Unit, Retrieved January 24, 2006, from www.deakin.edu.au/planning-unit/statistics/pocket/2006.php

Goold, A. \& Coldwell, J. (2005). Teaching ethics in a virtual classroom. ITiCSE '05, Monte de Caparica, Portugal, ACM.

Goodyear, P., Salmon, G., Spector, J., Steeples, C., \& Tickner, S. (2001). Competences for online teaching. Educational Technology Research and Development, 49, 65-72.

Haywood, J., Macleod, H., Haywood, D., Mogey, N., \& Alexander, W. (2004). The student view of ICT in education at the University of Edinburgh: Skills, attitudes \& expectations. Proceedings of the Association for Learning Technologies Conference, September 13-16, Exeter, UK.

Herrington, J. \& Oliver, R. (2002). Identification of generic ICT based software tools. Report produced as a research task for the AUTC Project: Information and Communication Technologies and Their Role in Flexible Learning.

Jarvis, P. (1995). Adult and continuing education: theory and practice (2nd ed.). New York: Routledge.

Keller, C., \& Cernerud, L. (2002). Students' perceptions of e-learning in university education. Journal of Educational Media, 27(1-2), 55 - 67.

King, A. (1993). From a sage on the stage to guide on the side. College Teaching, 41(1), 30 - 35.

Lai, K. W. (1999). Designing web-based learning environments. In K. W. Lai (Ed.), Net-working: Teaching, learning and professional development with the Interne (pp. 123-142). Dunedin: University of Otago Press.

Lefoe, G., Gunn, C., \& Hedberg, J. (2002). Recommendations for teaching in a distributed learning environment: The students' perspective. Australian Journal of Educational Technology, 18(1), 40-56.

Lockyer, L., \& Bennett, S. (2006). Understanding roles within technology supported teaching and learning: Implications for staff, academic units, and institutions. Technology Supported Learning and Teaching A staff perspective (pp. 210-223). London: Idea Group.

McShane, K. (2000). The online academic: Case study narratives of change and resistance, Retrieved 9 February, 2006, from http://www.ascilite.org.au/conferences/coffs00/a2k_main_conf04.html 
Mazzolini, M., \& Maddison, S. (2006). The role of the online instructor as a guide on the side. In J. O'Donoghue, Technology Supported Learning and Teaching- A staff perspective (pp. 224-241). London, Idea Group.

Newlands, D., \& Coldwell, J. (2005). Managing student expectations online. Lecture Notes in Computer Science, LNCS 3583, 355-363. Germany: Springer-Verlag.

Palloff, R., \& Pratt, K. (1998). Effective teaching and learning in the virtual classroom. World Computer Congress: Teleteaching 98, Vienna/Austria and Budapest/Hungary, August.

Quek, C., \& Wong, A .F. L. (2003). Evaluating e-learning environments in Singapore. In M. Khine \& D. Fisher (Eds.) Technology-rich learning environments: A future perspective. Singapore: World Scientific Publishing.

Salmon, G. (2001). Plenary address: Creating the e-learning experience (Which way is forward?). BEST conference, Windermere UK.

Salmon, G. (2002). Keynote - Pedagogical requirements of virtual learning environments (VLEs): PETS and PLANETS. The 24 hour University: Stretching the limits. UCISA TLIG-SDG User Support Conference, Leeds UK.

Salmon, G. (2005). Flying not flapping: A strategic framework for e-learning and pedagogical innovation in higher education institutions. Alt-J, Research in Learning Technologies, 13(3), 201-218.

Singh, G., O'Donoghue, J., \& Worton, H. (2005). A study into the effects of elearning on higher education. Journal of University Teaching and Learning Practice, 2(2), 13-24.

Smith, P., Coldwell, J., Smith, S. N., \& Murphy, K. (2005). Learning through computer-communicated communication: A comparison of Australian and Chinese heritage students. Innovations in Education and Teaching International, 42(2), 123-134.

Stacey, E. (2000). Quality online participation: Establishing social presence. In T. Evans, Research in Distance Education 5: Revised papers from the 5th Research in Distance Education conference (pp. 138153). Deakin University, Geelong.

Thomas, S. (2004). Using web and paper questionnaires for data-based decision making: From design to interpretation of the results. Thousand Oaks, California Corwin Press.

Wang, Q. (2006). Quality assurance- Best practices for assessing online programs. International Journal on E-Learning, 5(2), 265-274.

Zariski, A., \& Styles, I. (2000). Enhancing student strategies for online learning. Retrieved February 9, 2006 from http://cea.curtin.edu.au/tlf/tlf2000/zariski.html 


\section{Appendix (Tables 6 - 11)}

The tables listed in this appendix show the results of the statistical tests referenced in the paper. The results in the shaded cells are statistically significantly different from other groups. Results in italics are not valid as the assumptions of the Chi-square distribution have not been met.

\begin{tabular}{|c|c|c|c|c|}
\hline \multicolumn{5}{|c|}{ Table 6: Results of Chi-Square Tests: Teacher's Role vs. Campus } \\
\hline & & Chi-Square & df & $\begin{array}{c}\mathrm{p}- \\
\text { value }\end{array}$ \\
\hline T1 & Provide useful feedback on my work & 29.141 & 4 & 0.000 \\
\hline T3 & Challenge me to think about an issue & 57.331 & 4 & 0.000 \\
\hline T4 & Provide stimulating experiences & 37.465 & 4 & 0.000 \\
\hline T5 & Provide challenging experiences & 31.154 & 4 & 0.000 \\
\hline T6 & Help me to learn & 11.190 & 4 & 0.025 \\
\hline T8 & Use language that I can understand & 33.643 & 4 & 0.000 \\
\hline T9 & Tell me exactly what I need to know & 98.231 & 4 & 0.000 \\
\hline T10 & Tell me how to do things & 95.789 & 4 & 0.000 \\
\hline $\mathrm{T} 12$ & Speak my Language & 29.903 & 4 & 0.000 \\
\hline $\mathrm{T} 13$ & Tell me when to do things & 53.832 & 4 & 0.000 \\
\hline T14 & Know all the answers & 47.064 & 4 & 0.000 \\
\hline
\end{tabular}

\begin{tabular}{|c|c|c|c|c|c|c|c|}
\hline & Table 7: Results of $\mathrm{T}$ & ache & vs. Ca & pus: Pos & loc analy & & \\
\hline & & & & Stan & ardized $\mathbf{R e}$ & iduals & \\
\hline & & & City & Country & Distance & Overseas & Regional \\
\hline T1 & Provide useful feedback on my work & Yes & -0.7 & 0.2 & 0.7 & -1.1 & 0.5 \\
\hline & & No & 2.3 & -0.5 & -2.3 & $\begin{array}{r}3.7 \\
\text { Not Valid }\end{array}$ & -1.6 \\
\hline T3 & Challenge me to think about an issue & Yes & -1.5 & 0.5 & 2.0 & -2.7 & 0.6 \\
\hline & & No & 2.6 & -0.9 & -3.4 & 4.8 & -1.0 \\
\hline $\mathrm{T} 4$ & Provide stimulating experiences & Yes & -0.1 & 0.6 & -1.6 & -1.4 & 2.2 \\
\hline & & No & 0.1 & -1.1 & 2.7 & 2.4 & -3.7 \\
\hline T5 & Provide challenging experiences & Yes & -0.4 & 1.4 & -0.8 & -1.8 & 1.6 \\
\hline & & No & 0.7 & -2.3 & 1.3 & 3.0 & -2.6 \\
\hline T6 & Help me to learn & Yes & 0.5 & 0.5 & -1.3 & -0.7 & 0.8 \\
\hline & & No & -0.8 & -0.7 & 2.0 & 1.1 & $\begin{array}{l}-1.2 \\
\end{array}$ \\
\hline T8 & Use language that I can understand & Yes & 0.6 & 0.7 & -2.3 & -2.4 & 2.3 \\
\hline & & No & -0.6 & -0.7 & 2.2 & 2.4 & -2.3 \\
\hline T9 & Tell me exactly what I need to know & Yes & 4.4 & 0.0 & -5.9 & 1.3 & 0.1 \\
\hline & & No & -3.8 & 0.0 & 5.1 & -1.1 & -0.1 \\
\hline T10 & Tell me how to do things & Yes & 4.8 & 0.9 & -6.3 & 0.6 & -0.2 \\
\hline & & No & -3.4 & -0.7 & 4.5 & -0.5 & 0.2 \\
\hline T12 & Speak my Language & Yes & 0.7 & 1.3 & -3.3 & -1.6 & 2.9 \\
\hline & & No & -0.3 & -0.6 & 1.6 & 0.8 & -1.4 \\
\hline T13 & Tell me when to do things & Yes & 4.3 & 1.0 & -4.7 & 0.4 & $\begin{array}{l}-1.4 \\
\end{array}$ \\
\hline & & No & -2.0 & -0.5 & 2.2 & -0.2 & 0.7 \\
\hline T14 & Know all the answers & Yes & 3.1 & 0.5 & -5.0 & 2.2 & 0.3 \\
\hline & & No & -1.4 & -0.2 & 2.2 & -0.9 & -0.1 \\
\hline
\end{tabular}


Table 8: Results of Chi-Square Tests: Student's role vs. Campus

\begin{tabular}{|l|l|c|c|c|}
\hline & & Chi-Square & df & p-value \\
\hline S1 & Be self-motivated & 42.756 & 4 & 0.000 \\
\hline S3 & Submit work which is my own & 29.838 & 4 & 0.000 \\
\hline S8 & Be prepared for classes & 79.183 & 4 & 0.000 \\
\hline
\end{tabular}

Table 9: Results of Student's Role vs. Campus: Posthoc analysis

\begin{tabular}{|c|c|c|c|c|c|c|c|}
\hline & & & \multicolumn{5}{|c|}{ Standardized Residuals } \\
\hline & & & City & Country & Distance & Overseas & Regional \\
\hline \multirow[t]{2}{*}{ S1 } & \multirow[t]{2}{*}{ Be self-motivated } & Yes & -1.1 & 0.5 & 1.3 & -1.2 & 0.3 \\
\hline & & No & 3.2 & -1.3 & -3.8 & 3.4 & -0.7 \\
\hline \multirow[t]{2}{*}{ S3 } & \multirow[t]{2}{*}{ Submit work which is my own } & Yes & -0.7 & 0.3 & 0.7 & -1.5 & 0.6 \\
\hline & & No & 1.9 & -0.8 & -1.9 & 4.0 & -1.5 \\
\hline \multirow[t]{2}{*}{ S8 } & \multirow[t]{2}{*}{ Be prepared for classes } & Yes & 1.5 & 1.1 & -3.4 & -0.3 & 1.6 \\
\hline & & No & -2.7 & -2.0 & 6.4 & 0.6 & -2.9 \\
\hline
\end{tabular}

Table 10: Results of Chi-Square Tests: Students' expectations vs. Campus

\begin{tabular}{|l|l|c|c|c|}
\hline \multicolumn{2}{|l|}{} & Chi-Square & df & p-value \\
\hline E4 & $\begin{array}{l}\text { My focus is on making the most of all the opportunities that } \\
\text { are available. }\end{array}$ & 95.176 & 8 & 0.000 \\
\hline E5 & $\begin{array}{l}\text { My focus is on completing my course as quickly as possi- } \\
\text { ble. }\end{array}$ & 90.044 & 8 & 0.000 \\
\hline E7 & I accept what we are taught without questioning it much. & 83.043 & 8 & 0.000 \\
\hline E9 & $\begin{array}{l}\text { I am prepared to ask other students for help whenever I am } \\
\text { unsure of anything. }\end{array}$ & 158.520 & 8 & 0.000 \\
\hline E10 & My participation in scheduled classes is important & 483.760 & 8 & 0.000 \\
\hline
\end{tabular}




\begin{tabular}{|c|c|c|c|c|c|c|c|}
\hline \multicolumn{8}{|c|}{ Table 11: Results of Students' Expectations vs. Campus: Posthoc analysis } \\
\hline & & & \multicolumn{5}{|c|}{ Standardized Residuals } \\
\hline & & & City & Country & Distance & Overseas & Regional \\
\hline \multirow[t]{3}{*}{ E4 } & \multirow{3}{*}{$\begin{array}{l}\text { My focus is on making the } \\
\text { most of all the opportuni- } \\
\text { ties that are available. }\end{array}$} & Agree & 0.3 & 1.1 & -3.5 & 1.2 & 2.9 \\
\hline & & Neutral & 0.4 & -1.4 & 3.1 & -1.1 & -3.4 \\
\hline & & Disagree & -2.1 & $\begin{array}{r}-0.8 \\
\text { Not Valid } \\
\end{array}$ & 5.6 & $\begin{array}{r}-1.7 \\
\text { Not Valid }\end{array}$ & -2.7 \\
\hline \multirow[t]{3}{*}{ E5 } & \multirow{3}{*}{$\begin{array}{l}\text { My focus is on completing } \\
\text { my course as quickly as } \\
\text { possible. }\end{array}$} & Agree & 1.9 & 1.0 & -3.7 & 0.8 & 0.9 \\
\hline & & Neutral & 0.2 & -0.5 & 0.9 & 0.3 & -1.3 \\
\hline & & Disagree & -4.3 & -1.4 & 6.5 & -2.0 & -0.2 \\
\hline \multirow[t]{3}{*}{ E7 } & \multirow{3}{*}{$\begin{array}{l}\text { I accept what we are } \\
\text { taught without questioning } \\
\text { it much. }\end{array}$} & Agree & 0.7 & 1.1 & -2.6 & -0.6 & 1.8 \\
\hline & & Neutral & 2.3 & 0.8 & -3.7 & 2.7 & -0.3 \\
\hline & & Disagree & -2.6 & -1.6 & 5.4 & -1.9 & -1.3 \\
\hline \multirow[t]{3}{*}{ E9 } & \multirow{3}{*}{$\begin{array}{l}\text { I am prepared to ask other } \\
\text { students for help whenever } \\
\text { I am unsure of anything. }\end{array}$} & Agree & 1.8 & 1.1 & -5.2 & 0.2 & 3.1 \\
\hline & & Neutral & -1.0 & -1.7 & 4.3 & 1.1 & -3.3 \\
\hline & & Disagree & -3.2 & -0.2 & 7.5 & $\begin{array}{r}-2.2 \\
\text { Not Valid }\end{array}$ & -3.4 \\
\hline \multirow[t]{3}{*}{ E10 } & \multirow{3}{*}{$\begin{array}{l}\text { My participation in sched- } \\
\text { uled classes is important }\end{array}$} & Agree & 5.1 & 3.4 & -11.7 & 1.5 & 4.4 \\
\hline & & Neutral & -4.9 & -3.1 & 11.3 & -1.0 & -4.6 \\
\hline & & Disagree & -3.7 & -2.9 & 8.4 & -1.8 & -2.7 \\
\hline
\end{tabular}

\section{Biographies}

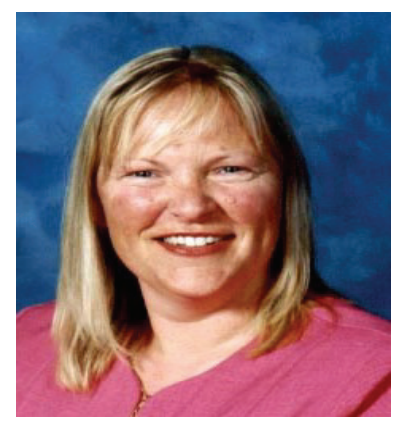

Annemieke Craig is senior lecturer in the School of Information Systems at Deakin University, Australia. Annemieke has been involved in numerous research investigations concerning the attraction, retention and advancement of women in the ICT area.

Annemieke's research interests also include issues related to online learning and website usability.

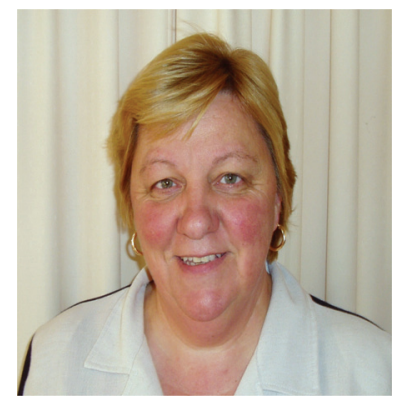

Annegret Goold is a lecturer in the School of Engineering and Information Technology at Deakin University, Australia. Prior to joining Deakin in 1993 she worked as a computer programmer, analyst, technical writer and trainer. At present she teaches introductory IT, project management and IT practice, and supervises projects in the capstone course. Annegret's research aligns with her teaching areas as well as in computer science education, particularly in online teaching and learning. 


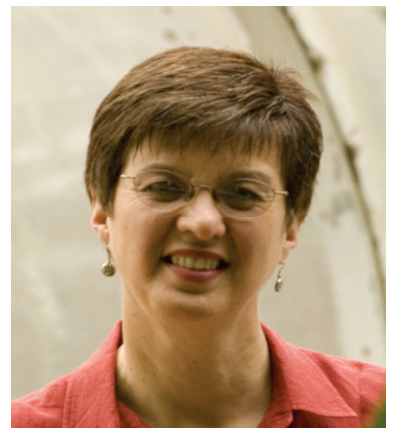

Jo Coldwell is Associate Head (Teaching and Learning) in the School of Engineering and Information Technology at Deakin University, Australia. Before becoming an academic, Jo had extensive industrial experience in the UK and Australia as a programmer, analyst and project leader. Her teaching includes database, systems analysis and design and professional practice. Jo's research revolves around elearning, particularly the use of technology to support, and its impact on, teaching and learning.

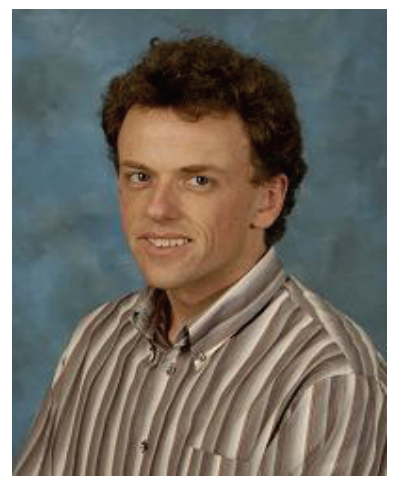

Jamie Mustard is a senior lecturer in the School of Information Systems at Deakin University, Australia. He teaches in the areas of software development, eCommerce, web-based technologies and quantitative methods.

Jamie's research interests include experimental design, applied statistics, and computational mathematics. 